\title{
Phosphorus, Potassium and Sulfur Interactions in Soybean Plants on a Typic Hapludox
}

\section{A. Moreira, L. A. C. Moraes, L. G. Moretti \& G. S. Aquino}

To cite this article: A. Moreira, L. A. C. Moraes, L. G. Moretti \& G. S. Aquino (2018) Phosphorus, Potassium and Sulfur Interactions in Soybean Plants on a Typic Hapludox, Communications in Soil Science and Plant Analysis, 49:4, 405-415, DOI: 10.1080/00103624.2018.1427262

To link to this article: https://doi.org/10.1080/00103624.2018.1427262

\section{曲 Published online: 01 Feb 2018.}

Submit your article to this journal $\pi$

LII Article views: 119

View Crossmark data ¿ 


\title{
Phosphorus, Potassium and Sulfur Interactions in Soybean Plants on a Typic Hapludox
}

\author{
A. Moreira ${ }^{a}$, L. A. C. Moraes ${ }^{a}$, L. G. Morettib, and G. S. Aquino \\ ${ }^{a}$ Department of Soil Science and Plant Nutrition of the National Soybean Research Center of Brazilian Agricultural \\ Research Corporation (EMBRAPA), Londrina, Brazil; ' ${ }^{2}$ epartment of Crop Science of the São Paulo State University, \\ Campus at Ilha Solteira, São Paulo State, Brazil; 'Department of Crop Science, State University at Londrina, Londrina, \\ Brazil
}

\begin{abstract}
Soybean (Glycine max (L.) Merril) has the largest acreage in Brazil where nutrients are provided to crops by formulated fertilizers, which is the most usual method. Under tropical and subtropical conditions, most of the nutrients required by soybean crops are phosphorus $(\mathrm{P})$ and potassium $(\mathrm{K})$, while sulfur $(\mathrm{S})$ is applied in smaller amounts. The $\mathrm{P}, \mathrm{K}$, and $\mathrm{S}$ interactions under greenhouse conditions using completely randomized blocks in a factorial $3 \times 3 \times 3$ arrangement were evaluated. The treatments were as follows: three $P$ rates $\left(0,75\right.$, and $\left.150 \mathrm{mg} \mathrm{P} \mathrm{kg}^{-1}\right)$; three $\mathrm{K}$ rates $(0,150$, and $\left.300 \mathrm{mg} \mathrm{K} \mathrm{kg}^{-1}\right)$; and three $S$ rates $\left(0,50\right.$, and $\left.100 \mathrm{mg} \mathrm{S} \mathrm{kg}^{-1}\right)$. The $\mathrm{P}, \mathrm{K}$, and $\mathrm{S}$ application had a significant influence on the shoot dry weight (SDW) and number of pods per pot (NPP) in contrast with the increase in grain yield (GY) that had positive relationship with $\mathrm{K}$ and $\mathrm{S}$ rates. These results indicated that both nutrients were the most limiting to GY. In soil and leaves, only the $\mathrm{P}, \mathrm{K}$, and $\mathrm{S}$ concentrations were modified by the treatments $(\mathrm{P}, \mathrm{K}$, and $S$ ), but in the grains there was synergism of $P$ rates with $\mathrm{Mg}$ concentration unlike $\mathrm{K}$ rates with $\mathrm{Ca}$ concentration. Physiological components as photosynthetic rate, intrinsic efficiency of water use, and chlorophyll had influence from $\mathrm{P}$ and $\mathrm{K}$ rates.
\end{abstract}

\section{ARTICLE HISTORY}

Received 4 July 2017

Accepted 17 November 2017

\section{KEYWORDS}

Glycine max; grain yield; nutritional status; physiological components; yield components

\section{Introduction}

Liming and fertilizer application are important decisions made by plant growers with the aim of increasing the productivity of soybean growing in soils highly weathered under tropical and subtropical regions. These soils are characterized by the high acidity and predominance of hydrogen $\left(\mathrm{H}^{+}\right)$and aluminum $\left(\mathrm{Al}^{+3}\right)$ in cation exchange complex (Fageria and Baligar 2008; Foy 1984). In soybean crops, the positive fertilizer effects in the productivity are reported from several experiments under these edaphoclimatic conditions, and after applying different liming sources and macronutrients as $\mathrm{P}$ and $\mathrm{K}$ alone or from formulated fertilizers with N-P-K plus sulfate $\left(\mathrm{S}_{-} \mathrm{SO}_{4}{ }^{2-}\right.$ ), dihydrated calcium sulfate (gypsum) (Sfredo, Paludziyzyn Filho, and Gomes 1994; Fageria et al. 2013; 2014; Moreira et al. 2014; Sfredo and Moreira 2015), or S element (Broch et al. 2011).

The nutrient interaction in plants may be classified as positive, negative, or neutral when they interfere in uptake and other nutrient use, and their effects are quantified by GY, nutritional status of plants, and yield components under the different levels applied into the soil (Adams 1984; Fageria and Oliveira 2014). Fageria (2009) reported increases in phosphorus (P), potassium (K), and sulfur (S) in plants associated with increases in GY, SDW, and root dry weight (RDW). In contrast, reports 
from Adams (1984) noticed interactions because of cation and anion balance in plants where organic acids have important physiological effects.

In plants, the aim of $\mathrm{P}$ is to store energy and transfer it to accomplish chemical reactions using adenosine triphosphate (ATP) in photosynthesis, nutrient uptake, and respiration. $\mathrm{K}$ controls osmotic processes, opening and closing stomata, and synthesis of protein, while $S$ is found in the aminoacid composition, photosynthesis, and symbiosis of nitrogen $(\mathrm{N})$ fixation among other metabolic achievements (Fageria 2009; Malavolta, Vitti, and Oliveira 1997; Marschner 2012).

The objective of this study was aimed to evaluate the effects P, K, and S interactions on GY, soil fertility, yield components, nutritional status, and physiological components of soybean plants cultivated in acid soil.

\section{Material and methods}

\section{Site and soil chemical characteristics}

A greenhouse experiment was conducted at the Embrapa Soja, in Londrina County, Paraná State, Brazil $\left(23^{\circ} 1^{\prime} 39^{\prime \prime} \mathrm{SL}, 51^{\circ} 10^{\prime} 40^{\prime \prime} \mathrm{WL}\right)$, to evaluate the P, K, and S interaction on soil fertility, yield components, grain yield (GY), physiological components, and nutritional status of plants. The soil used was a Typic Hapludox collected at $0-20 \mathrm{~cm}$ with the following chemical attributes: $\mathrm{pH}\left(\mathrm{CaCl}_{2}\right)=4.9$, available $\mathrm{P}=3.9$ $\mathrm{mg} \mathrm{kg}{ }^{-1}$, carbon $(\mathrm{C})=8.5 \mathrm{~g} \mathrm{~kg}^{-1}, \mathrm{Al}^{3+}=0.1 \mathrm{cmol}_{\mathrm{c}} \mathrm{kg}^{-1}$, potential acidity $\left(\mathrm{H}^{+}+\mathrm{Al}^{3+}\right)=1.8 \mathrm{cmol}_{\mathrm{c}} \mathrm{kg}^{-1}$, calcium $\left(\mathrm{Ca}^{2+}\right)=1.6 \mathrm{cmol}_{\mathrm{c}} \mathrm{kg}^{-1}$, magnesium $\left(\mathrm{Mg}^{2+}\right)=0.6 \mathrm{cmol}_{\mathrm{c}} \mathrm{kg}^{-1}, \mathrm{~K}^{+}=0.1 \mathrm{cmol}_{\mathrm{c}} \mathrm{kg}^{-1}$, cation exchange capacity $(\mathrm{CEC})=4.1 \mathrm{cmol}_{\mathrm{c}} \mathrm{kg}^{-1}, \mathrm{~S}_{-} \mathrm{SO}_{4}{ }^{2-}=4.9 \mathrm{mg} \mathrm{kg}^{-1}$, and clay $=420 \mathrm{~g} \mathrm{~kg}^{-1}$. The available $\mathrm{P}$ and exchangeable $\mathrm{K}^{+}$were extracted by Mehlich 1 solution $[0.05 \mathrm{M}$ hydrochloric acid $(\mathrm{HCl})+0.025 \mathrm{M}$ sulfuric acid $\left.\left(\mathrm{H}_{2} \mathrm{SO}_{4}\right)\right], \mathrm{Al}^{3+}, \mathrm{Ca}^{2+}$ and $\mathrm{Mg}^{2+}$ using potassium chloride $(\mathrm{KCl}) 1.0 \mathrm{~mol} \mathrm{~L}^{-1}, \mathrm{C}$ by WalkleyBlack, and $\mathrm{H}^{+}+\mathrm{Al}^{3+}$ using the buffer solution pH-SMP (Shoemaker, Maclean, and Pratt). All of the analysis methods are available in Embrapa (1997).

The experimental design included completely randomized blocks using the $3 \times 3 \times 3$ factorial arrangement with three replicates, where we set three $\mathrm{P}$ rates $\left(0,75\right.$, and $150 \mathrm{mg} \mathrm{P} \mathrm{kg}{ }^{-1}$, source: monoammonium phosphate-MAP); three $\mathrm{K}$ rates $\left(0,150\right.$, and $300 \mathrm{mg} \mathrm{K} \mathrm{kg}{ }^{-1}$, source: potassium chloride- $\mathrm{KCl})$; and three $\mathrm{S}$ rates $\left(0,50\right.$, and $100 \mathrm{mg} \mathrm{S} \mathrm{kg}^{-1}$, source: the elementary $\mathrm{S}$ with purity at 95\%). The $\mathrm{P}$ and $\mathrm{S}$ rates were applied before seed sowing, and the $\mathrm{K}$ rates were partitioned into three applications $(2 / 4$ before the seed sowing, $1 / 4$ at V2 growth stage and $1 / 4$ at V4 growth stage). The soybean cultivar TMG 1066RR (semi-determined growth habit and maturity group 6.2) was utilized in the experiment. We sowed 10 seeds and after germination, two plants were maintained in each pot of $3 \mathrm{~kg}$ of soil.

We apply the equivalent of $3 \mathrm{t} \mathrm{ha}^{-1}$ of dolomite lime [(27.8\% in calcium oxide $(\mathrm{CaO}), 19.6 \%$ de magnesium oxide $(\mathrm{MgO})$ and the equivalence in calcium carbonate $(\mathrm{ECC})=85 \%] 3$ days before seed sowing. Except $\mathrm{P}, \mathrm{K}$, and $\mathrm{S}$, fertilizers with $\mathrm{B}, \mathrm{Co}, \mathrm{Cu}, \mathrm{Fe}, \mathrm{Mn}, \mathrm{Mo}$, Ni. and $\mathrm{Zn}$ followed the recommendations from Moreira, Fageria, and Garcia Y Garcia (2011) after adaptation from Allen, Terman, and Clements (1976) for experiments under greenhouse conditions $\left[0.5 \mathrm{mg} \mathrm{kg}{ }^{-1} \mathrm{de} \mathrm{B}\right.$ $\left(\mathrm{H}_{3} \mathrm{BO}_{3}\right), 1.5 \mathrm{mg} \mathrm{kg}^{-1}$ of $\mathrm{Cu}\left(\mathrm{CuSO}_{4} \times 7 \mathrm{H}_{2} \mathrm{O}\right), 0.1 \mathrm{mg} \mathrm{kg}^{-1}$ of $\mathrm{Mo}\left(\mathrm{Na}_{2} \mathrm{Mo}_{4} \times 2 \mathrm{H}_{2} \mathrm{O}\right), 2.5 \mathrm{mg} \mathrm{kg}^{-1}$ of $\mathrm{Fe}\left(\mathrm{FeSO}_{4} \times 2 \mathrm{H}_{2} \mathrm{O}\right), 0.01 \mathrm{mg} \mathrm{kg}^{-1}$ de $\mathrm{Co}\left(\mathrm{CoCl}_{2}\right), 0.01 \mathrm{mg} \mathrm{kg}{ }^{-1}$ of $\mathrm{Ni}\left(\mathrm{NiSO}_{4} \times 6 \mathrm{H}_{2} \mathrm{O}\right), 5.0 \mathrm{mg} \mathrm{kg}$ of $\mathrm{Mn}\left(\mathrm{MnSO}_{4} \times 3 \mathrm{H}_{2} \mathrm{O}\right)$, and $5.0 \mathrm{mg} \mathrm{kg}{ }^{-1}$ of $\left.\mathrm{Zn}\left(\mathrm{ZnSO}_{4} \times 7 \mathrm{H}_{2} \mathrm{O}\right)\right]$. The pots were irrigated to maintain $70 \%$ of the total values of porous (TVP) using the method described by Cassel and Nielsen (1986).

\section{Plant harvesting and laboratory analyses}

During the morning period, we determined the photosynthetic rate, $A$ [ $\mu \mathrm{mol}$ carbon dioxide $\left(\mathrm{CO}_{2}\right)$ $\mathrm{m}^{-2} \mathrm{~s}^{-1}$ ], stomatal conductance, $g_{s}\left(\mathrm{~mol} \mathrm{H}_{2} \mathrm{O} \mathrm{M}^{-2} \mathrm{~s}^{-1}\right)$, transpiration, Trmmol $\left(\mathrm{mmol} \mathrm{H}_{2} \mathrm{O} \mathrm{m}^{-2} \mathrm{~s}^{-1}\right)$, and inner concentration of $\mathrm{CO}_{2}, \mathrm{Ci}\left(\mu \mathrm{mol} \mathrm{CO} \mathrm{CO}^{-1}\right)$. We also calculated the intrinsic water use 
efficiency, IWUE (A/Trmmol ratio) ( $\mu \mathrm{mol} \mathrm{CO}_{2} \mathrm{~m}^{-2} \mathrm{~s}^{-1}$ ) using a portable photosynthesis analyzer (LI-6400XT LICOR ${ }^{\oplus}$, Lincoln, NE, USA) in R2 growth stage (Fehr et al. 1971), which had the third and fourth trifoliate leaves from the plant apex. In this same stage, we determined the soil-plant analyses development (SPAD) value and converted in chlorophyll content $\left(\mathrm{mg} \mathrm{cm}^{-2}\right)$ using the equation $\hat{y}=16.033+(7.5774 \times \mathrm{SPAD})$ proposed by Fritschi and Ray (2007). Thereafter, we collected the trifoliate leaves from every treatment and dried all of them in a circulating oven dryer at $65^{\circ} \mathrm{C}$ to determine the N, P, K, Ca, Mg, and S concentration (Malavolta, Vitti, and Oliveira 1997).

During all of the vegetative stages, we collected senescent leaves to obtain the shoot dry weight (SDW). Finally, we quantified the GY, number of pod per pot (NPP), number of grain per pod (NGP), and NPP. The N, P, K, Ca, Mg, and S concentration in leaves was determined. The grain harvest index (GHI) and the relative yield (RY) were estimated by the following equations:

$$
\mathrm{GHI}=\mathrm{GY} /(\mathrm{SDW}+\mathrm{GY}) \text {; }
$$

$\mathrm{RY}(\%)=\left[\left(\mathrm{GY}\right.\right.$ in the treatment $\left.\mathrm{P}_{0} \mathrm{~K}_{0} \mathrm{~S}_{0}\right) / \mathrm{GY}$ in the treatments $\left.\left.\mathrm{P}_{x} \mathrm{~K}_{y} \mathrm{~S}_{w}\right)\right] \times 100$, where $x=\mathrm{P}$ rates $\left(0,75\right.$, and $\left.150 \mathrm{mg} \mathrm{kg}^{-1}\right) ; y=\mathrm{K}$ rates $\left(0,150\right.$, and $\left.300 \mathrm{mg} \mathrm{kg}^{-1}\right)$; and $w=\mathrm{S}$ rates $(0,50$, and 100 $\left.\mathrm{mg} \mathrm{kg}^{-1}\right)$.

\section{Statistical analyses}

The responses were investigated by normality tests (Hicks 1973), analysis of variance (ANOVA), and $F$-test, and the means of each treatments were discriminated by the Scott and Knott test at $\%$ of probability.

\section{Results and discussion}

\section{Component yield}

Treatments without $\mathrm{K}$ and S application significantly reduced the GY and SDW of soybean. In contrast, the NPP was reduced only without S (Tables 1 and 2). In GY, the K application was more effective with increases of 90 and $101 \%$ under 150 and $300 \mathrm{mg} \mathrm{K} \mathrm{kg}{ }^{-1}$ unlike with the $S$ application when the increase was only 35 and $41 \%$ under 50 and $100 \mathrm{mg} \mathrm{kg}^{-1}$ (Table 1). The P fertilization had increases of $12 \%$, which means that the presence of $\mathrm{P}$ at $3.9 \mathrm{~g} \mathrm{~kg}^{-1}$ (Mehlich 1) before sowing in a Typic Hapludox with $420 \mathrm{~g} \mathrm{~kg}^{-1}$ clay was satisfactory to supply the adequate quantity to plant along all cycles. Based on Baligar, Fageria, and He (2001) and Moreira, Moraes, and Fageria (2015), the NGP is under the control of genetic factors as verified in this experiment. Thus, NGP was similar with or without $\mathrm{P}, \mathrm{K}$, and $\mathrm{S}$ application, but we verified that without $\mathrm{K}$ fertilization there was grain with lower size, wrinkled and stretched out shape as reported by Borkert et al. (2005), and consequently with lower GY per pot.

The GY varied from $8.8 \mathrm{~g} /$ pot $\left(\mathrm{P}_{0} \mathrm{~K}_{0} \mathrm{~S}_{0}\right)$ to $32.3 \mathrm{~g} /$ pot $\left(\mathrm{P}_{1} \mathrm{~K}_{2} \mathrm{~S}_{2}\right)$, with an average value of $17.7 \mathrm{~g} / \mathrm{pot}$, and we detected significant correlation with NPP $(\hat{y}=35.907+1.371 x, r=0.54, p \leq 0.05)$. Corroborating the GY, the treatment $\mathrm{K}_{1} \mathrm{~K}_{2} \mathrm{~S}_{2}$ had lower RY, which means that GY from $\mathrm{P}_{0} \mathrm{~K}_{0} \mathrm{~S}_{0}$ was similar to $27.1 \%$ of the highest productivity, and the inverse was found with the treatments $\mathrm{P}_{2} \mathrm{~K}_{0} \mathrm{~S}_{2}$, where we find GY $98.0 \%$ out of control (Table 1). Among the treatments, the $\mathrm{K}$ and $\mathrm{S}$ interaction was significant, and without $\mathrm{K}$ application, the responses were independent of the satisfactory $\mathrm{P}$ and $\mathrm{S}$ levels with lower GY and higher RY (Tables 1 and 2). Pots without $\mathrm{P}, \mathrm{K}$, and $\mathrm{S}\left(\mathrm{P}_{0} \mathrm{~K}_{0} \mathrm{~S}_{0}\right)$ application had lower SDW yield and NPP in contrast to NGP that did not have influence from the treatments. We must highlight that the highest production of SDW was found in treatment $\mathrm{P}_{1} \mathrm{~K}_{0} \mathrm{~S}_{0}$, and the plant did not convert SDW into GY.

The negative results in the absence of $\mathrm{K}$, occurs because the element is the one that most limits the PG of the soybean and entails in smaller size of grains (Borkert et al. 2005). This occurs because of the high mobility in the xylem (Malavolta 2006; Marschner 2012), and the continuous demand of 
Table 1. Phosphorus (P), potassium (K), and sulfur (S) levels on shoot dry weight yield (SDWY), grain yield (GY), number of pods per pot (NPP), number of grains per pod (NGP), grain harvest index (GHI), and relative yield (RY) in soybean plants.

\begin{tabular}{|c|c|c|c|c|c|c|}
\hline & GY & SDW & NPP & NGP & & \\
\hline Treatments & (g/pot) & (g/pot) & $(\mathrm{n})$ & $(\mathrm{n})$ & $\mathrm{GHI}$ & RY \\
\hline $\mathrm{P}_{0} \mathrm{~K}_{0} \mathrm{~S}_{0}$ & 8.8 & 43.1 & 24 & 2.1 & 0.20 & - \\
\hline $\mathrm{P}_{0} \mathrm{~K}_{0} \mathrm{~S}_{1}$ & 11.2 & 50.2 & 67 & 2.2 & 0.22 & 78.6 \\
\hline $\mathrm{P}_{0} \mathrm{~K}_{0} \mathrm{~S}_{2}$ & 10.1 & 53.6 & 57 & 2.1 & 0.19 & 86.7 \\
\hline $\mathrm{P}_{0} \mathrm{~K}_{1} \mathrm{~S}_{0}$ & 20.4 & 62.7 & 71 & 2.4 & 0.37 & 43.1 \\
\hline $\mathrm{P}_{0} \mathrm{~K}_{1} \mathrm{~S}_{1}$ & 21.1 & 56.7 & 64 & 2.2 & 0.32 & 41.5 \\
\hline $\mathrm{P}_{0} \mathrm{~K}_{1} \mathrm{~S}_{2}$ & 20.9 & 56.8 & 60 & 2.1 & 0.37 & 41.9 \\
\hline $\mathrm{P}_{0} \mathrm{~K}_{2} \mathrm{~S}_{0}$ & 15.8 & 48.5 & 46 & 2.0 & 0.33 & 55.7 \\
\hline $\mathrm{P}_{0} \mathrm{~K}_{2} \mathrm{~S}_{1}$ & 21.3 & 63.7 & 50 & 2.1 & 0.34 & 41.2 \\
\hline $\mathrm{P}_{0} \mathrm{~K}_{2} \mathrm{~S}_{2}$ & 21.1 & 62.1 & 56 & 2.5 & 0.32 & 41.6 \\
\hline $\mathrm{P}_{1} \mathrm{~K}_{0} \mathrm{~S}_{0}$ & 12.9 & 88.5 & 42 & 2.2 & 0.17 & 68.2 \\
\hline $\mathrm{P}_{1} \mathrm{~K}_{0} \mathrm{~S}_{1}$ & 10.9 & 62.8 & 82 & 2.2 & 0.23 & 80.8 \\
\hline $\mathrm{P}_{1} \mathrm{~K}_{0} \mathrm{~S}_{2}$ & 15.5 & 67.4 & 96 & 2.1 & 0.23 & 56.5 \\
\hline $\mathrm{P}_{1} \mathrm{~K}_{1} \mathrm{~S}_{0}$ & 15.7 & 66.3 & 41 & 2.4 & 0.24 & 56.0 \\
\hline $\mathrm{P}_{1} \mathrm{~K}_{1} \mathrm{~S}_{1}$ & 23.0 & 61.7 & 77 & 2.5 & 0.38 & 38.1 \\
\hline $\mathrm{P}_{1} \mathrm{~K}_{1} \mathrm{~S}_{2}$ & 13.4 & 73.3 & 62 & 2.3 & 0.18 & 65.3 \\
\hline $\mathrm{P}_{1} \mathrm{~K}_{2} \mathrm{~S}_{0}$ & 10.9 & 56.4 & 38 & 2.4 & 0.37 & 80.6 \\
\hline $\mathrm{P}_{1} \mathrm{~K}_{2} \mathrm{~S}_{1}$ & 23.8 & 77.5 & 64 & 2.1 & 0.19 & 36.8 \\
\hline $\mathrm{P}_{1} \mathrm{~K}_{2} \mathrm{~S}_{2}$ & 32.3 & 55.5 & 88 & 2.0 & 0.31 & 27.1 \\
\hline $\mathrm{P}_{2} \mathrm{~K}_{0} \mathrm{~S}_{0}$ & 10.9 & 49.1 & 41 & 2.2 & 0.16 & 80.6 \\
\hline $\mathrm{P}_{2} \mathrm{~K}_{0} \mathrm{~S}_{1}$ & 9.0 & 53.2 & 54 & 2.3 & 0.22 & 98.0 \\
\hline $\mathrm{P}_{2} \mathrm{~K}_{0} \mathrm{~S}_{2}$ & 9.2 & 59.3 & 61 & 2.2 & 0.17 & 95.1 \\
\hline $\mathrm{P}_{2} \mathrm{~K}_{1} \mathrm{~S}_{0}$ & 18.4 & 63.5 & 60 & 2.4 & 0.36 & 47.8 \\
\hline $\mathrm{P}_{2} \mathrm{~K}_{1} \mathrm{~S}_{1}$ & 23.5 & 65.6 & 67 & 2.1 & 0.36 & 37.3 \\
\hline $\mathrm{P}_{2} \mathrm{~K}_{1} \mathrm{~S}_{2}$ & 28.7 & 80.3 & 83 & 2.1 & 0.29 & 30.5 \\
\hline $\mathrm{P}_{2} \mathrm{~K}_{2} \mathrm{~S}_{0}$ & 13.5 & 52.5 & 32 & 2.2 & 0.26 & 64.8 \\
\hline $\mathrm{P}_{2} \mathrm{~K}_{2} \mathrm{~S}_{1}$ & 27.4 & 77.2 & 71 & 2.3 & 0.35 & 32.0 \\
\hline $\mathrm{P}_{2} \mathrm{~K}_{2} \mathrm{~S}_{2}$ & 28.1 & 79.8 & 71 & 2.2 & 0.35 & 31.2 \\
\hline Mean & 17.7 & 62.5 & 60 & 2.2 & 0.28 & 56,0 \\
\hline \multicolumn{7}{|l|}{$\mathrm{F}$ test } \\
\hline P & ns & * & * & ns & ns & - \\
\hline K & * & * & * & ns & * & - \\
\hline$S$ & * & * & * & ns & ns & - \\
\hline$P \times K$ & ns & * & ns & ns & ns & - \\
\hline$P \times S$ & ns & * & ns & ns & ns & - \\
\hline $\mathrm{K} \times \mathrm{S}$ & * & * & ns & ns & ns & - \\
\hline $\mathrm{P} \times \mathrm{K} \times \mathrm{S}$ & ns & ns & ns & ns & ns & - \\
\hline$C V, \%$ & 16.5 & 17.8 & 18.9 & 11.5 & 17.5 & - \\
\hline
\end{tabular}

*Means significantly different at $p \leq 0.05$; ns, nonsignificant difference.

Table 2. Phosphorus (P), potassium (K), and sulfur (S) levels on shoot dry weight yield (SDWY), grain yield (GY), number of pods per pot (NPP), and number of grains per pod (NGP) in soybean plants.

\begin{tabular}{|c|c|c|c|c|c|}
\hline & Rates & $\mathrm{GY}$ & SDW & NPP & NGP \\
\hline Treatments & $\left(\mathrm{mg} \mathrm{kg}^{-1}\right)$ & (g/pot) & (g/pot) & (n) & (n) \\
\hline \multirow[t]{3}{*}{$P$} & $0(1)$ & $16.7 \mathrm{a}$ & $55.3 b$ & $55.0 a$ & 2.2 \\
\hline & $75(2)$ & $17.6 a$ & $67.7 a$ & $65.6 a$ & 2.1 \\
\hline & $150(3)$ & $18.7 \mathrm{a}$ & $64.5 a$ & $60.0 \mathrm{a}$ & 2.2 \\
\hline \multirow[t]{3}{*}{ K } & 0 (1) & $10.9 \mathrm{~b}$ & $54.9 \mathrm{~b}$ & $58.2 \mathrm{a}$ & 2.2 \\
\hline & $150(2)$ & $20.6 a$ & $65.2 a$ & $65.0 \mathrm{a}$ & 2.2 \\
\hline & $300(3)$ & $21.9 a$ & $67.4 a$ & $57.3 a$ & 2.1 \\
\hline \multirow[t]{3}{*}{$S$} & $0(1)$ & $14.1 \mathrm{~b}$ & $55.3 b$ & $43.9 \mathrm{~b}$ & 2.2 \\
\hline & $50(2)$ & $19.0 \mathrm{a}$ & $63.2 a$ & $63.2 \mathrm{a}$ & 2.1 \\
\hline & $100(3)$ & $19.9 a$ & $69.0 a$ & $70.4 a$ & 2.2 \\
\hline Mean & & 17.7 & 62.5 & 60.2 & 2.2 \\
\hline
\end{tabular}

Means significantly different at $p \leq 0.05$; ns, no significant difference.

Notes: In parentheses, the treatments of each variable $(P, K$, and $S)$; means followed by the same letters in the same column inside of each variable are not different at the $5 \%$ probability by Tukey's test. 
this nutrient during the grain formation all over the plant cycles of indeterminate soybean cultivars (Moreira, Moraes, and Fageria 2015). Wilson (1993) and Fageria and Oliveira (2014) reported that the response in plant growth and the plant GY to a specific nutrient is straightforward linked to satisfactory levels of other essential nutrients for plant development.

The significant K and S interaction in SDW (Table 1) was also verified by Usherwood (1982), who reported that the positive effect of $\mathrm{K}$ rates in the SDW yield of Centrosema pubescens was only effective when the $S$ level was satisfactory in the soil which was an unlikely fact in the current edaphoclimatic conditions, because $90 \%$ of tropical soils have levels below the satisfactory recommendations (Malavolta 2006). The significant reduction verified in GY from the treatments without S (Tables 1 and 2) corroborates with the results of Moreira and Moraes (2016), who studied the efficient use of this nutrient by soybean cultivars and stated an average reduction of $40 \%$ in GY when $\mathrm{S}$ was not applied (Table 1). GHI varied from $0.16\left(\mathrm{P}_{2} \mathrm{~K}_{0} \mathrm{~S}_{0}\right)$ to $0.38\left(\mathrm{P}_{1} \mathrm{~K}_{1} \mathrm{~S}_{1}\right)$, with an average value of 0.28 (Table 1). Fageria and Oliveira (2014) reported that GHI as an important index to determine the partition of SDW with GY. A value above 0.50 is the threshold of this relation, and lower harvesting indexes indicate the possibility of improving the biomass in SDW of plant.

\section{Soil chemical attributes}

In the soil (Table 3 ), only the $\mathrm{P}, \mathrm{K}$, and $\mathrm{S}_{-} \mathrm{SO}_{4}{ }^{2-}$ contents were significantly influenced by the treatments. Available $\mathrm{P}$ varied from 3.6 to $88.9 \mathrm{mg} \mathrm{kg}^{-1}$ and it was also negatively affected by $\mathrm{K}$ rates. The highest estimates of GY and SDW were detected in plants growing under the higher $\mathrm{K}$ rates (Table 2). It required a higher amount of available $\mathrm{P}$, which resulted in less nutrient loss in the soil after harvesting. Similarly, the available $\mathrm{S}_{-} \mathrm{SO}_{4}{ }^{2-}$ also reduced under higher $\mathrm{K}$ rates, and the inverse was verified in P rates (Table 3). Based on Rosolem (2005), the fertilization must be balanced in terms of proportion among nutrient quantities to allow the plants to express all of their productive potential. When growing plants in pots, We have a limited radicular system, where the nutrients available have restriction, irrespective of the quantity of roots.

The $\mathrm{pH}$ and the organic $\mathrm{C}$ content were above the range 5.5-6.0 and below the range 8.0-14.0 $\mathrm{g}$ $\mathrm{kg}^{-1}$ indicated as satisfactory, respectively by Tedesco et al. (1995) and TPS (2013) for soils under tropical and subtropical conditions. Among the treatments, the soil $\mathrm{pH}$ varied from 6.3 to 6.6 and the average value was 6.5 , and $\mathrm{C}$ varied from 6.6 to $7.1 \mathrm{~g} \mathrm{~kg}^{-1}$ with an average of $6.9 \mathrm{~g} \mathrm{~kg}^{-1}$ (Table 3). When we compared the soil before and after applying $3 \mathrm{t} \mathrm{ha}^{-1}$ of lime, there was increase in $\mathrm{pH}$, and decrease in organic $\mathrm{C}$ is the result from the soil reaction with the lime because the soil water releases anions $\mathrm{OH}^{-}$that neutralize the soil acidity and increase C organic mineralization (Foy 1984; Raij 2011). Despite the fact that the $S$ element promotes soil acidity in biological reaction to produce sulfate (Janzen and Bettany 1987), we did not find S rate effects on $\mathrm{pH}$ (Table 3). The large quantity of lime in the pots induced higher soil buffering on the sulfuric acid from the oxidation process (Fox et al. 1964). Based on Raij (2011), the soil $\mathrm{pH}$ increases above 5.5 neutralized exchangeable $\mathrm{Al}^{3+}$ and $\mathrm{H}^{+}+\mathrm{Al}^{3+}$. The CEC had estimates of $1.4 \mathrm{cmol}_{\mathrm{c}} \mathrm{kg}^{-1}$ and $4.7 \mathrm{cmol}_{\mathrm{c}} \mathrm{kg}^{-1}$ and they were not affected by the treatments (Table 3). Even after applying up to $300 \mathrm{mg} \mathrm{kg}^{-1}$, Fageria, Santos, and Moraes (2010) reported absence of $\mathrm{K}$ rates in common beans (Phaseolus vulgaris), and Moreira, Moraes, and Fageria (2015) also observed increases in CEC after applying $200 \mathrm{mg} \mathrm{K} \mathrm{kg}^{-1}$ in soybean.

\section{Nutrient concentration in leaves and grain}

The foliar and grain $\mathrm{P}, \mathrm{K}$, and $\mathrm{S}$ concentration had influence from $\mathrm{P}, \mathrm{K}$, and $\mathrm{S}$ rates. However, we did not find significant responses for the foliar $\mathrm{N}, \mathrm{Ca}$, and $\mathrm{Mg}$ concentration and $\mathrm{N}$ in the grain (Table 4). These results indicated that increases in the $\mathrm{P}$ rates increase the $\mathrm{P}$ uptake in the leaves and $\mathrm{P}, \mathrm{K}$, and $\mathrm{Mg}$ in the grain. These responses suggested that the modifications in $\mathrm{P}$ concentration are straightforward and related to increase of $\mathrm{P}$ rates in the soil. Significant effects of $\mathrm{P}$ rates on the K concentration in the plants were also described by Ward et al. (1963) and Fageria et al. (2016). In 


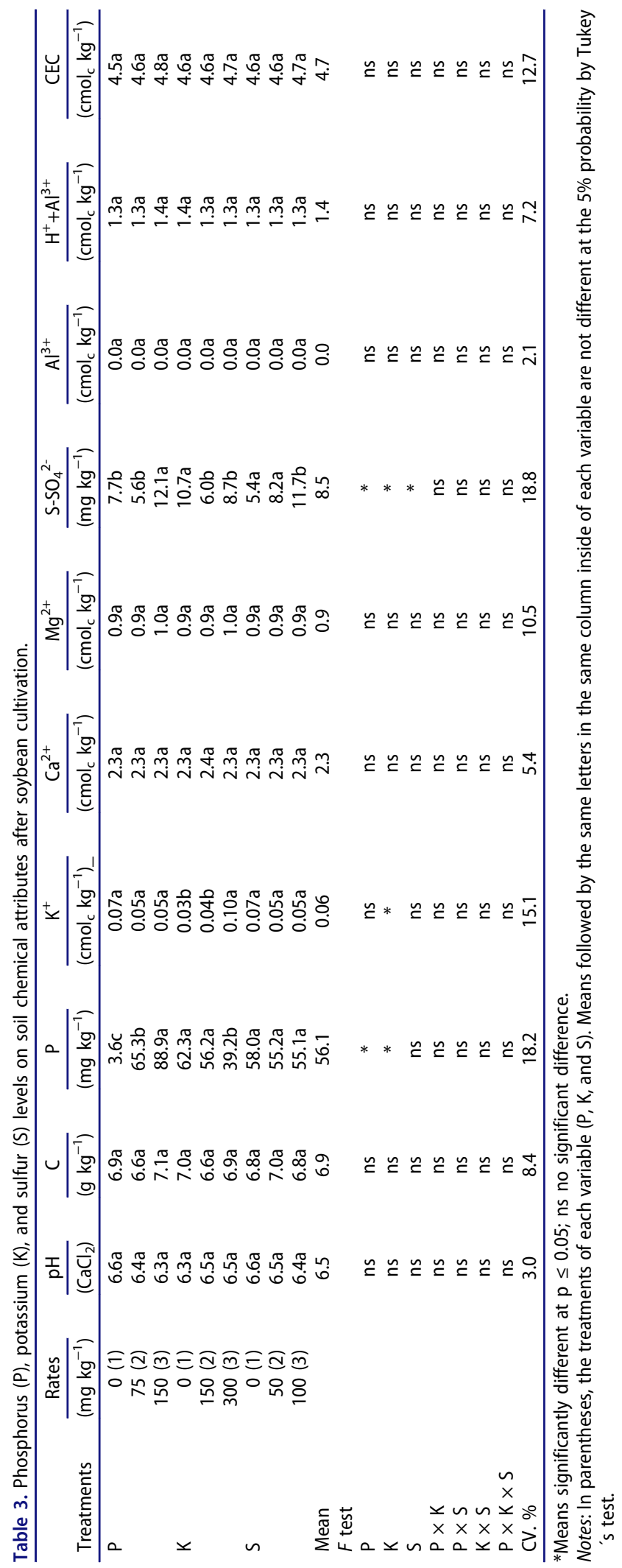




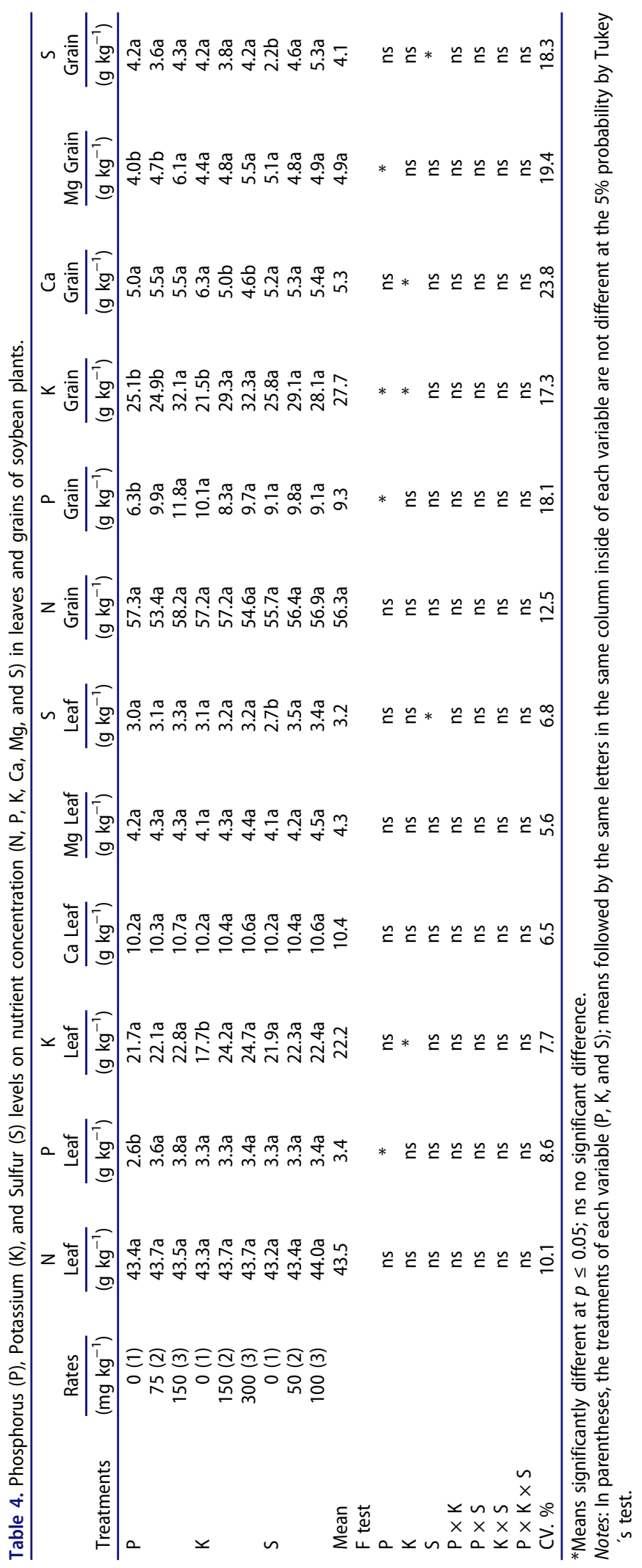




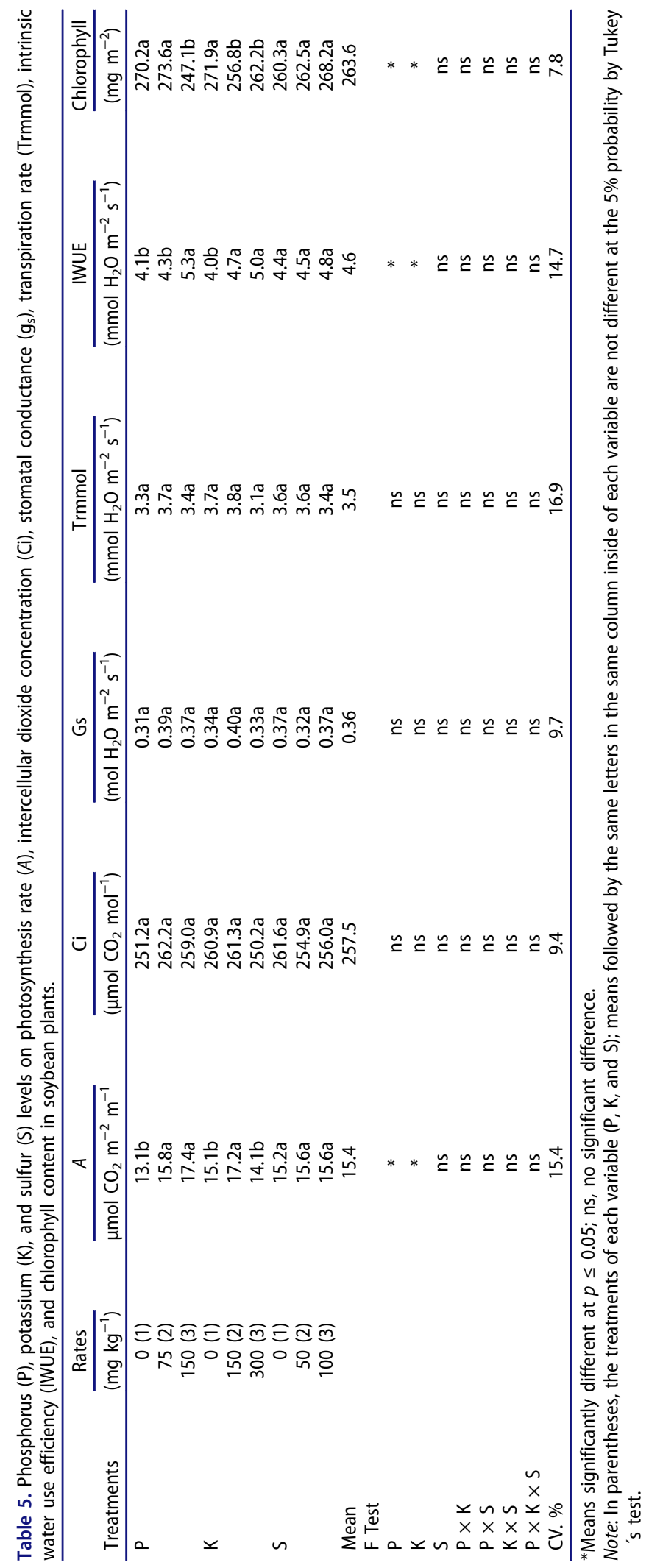


terms of Mg significance in grain, Zhong, Schobert, and Komor (1993) reported that the available P is decisive for Mg mobilization, uptake, and translocation into the plants. The limiting $\mathrm{K}$ effect in GY was verified through $\mathrm{K}$ concentration, because it was the only nutrient with significant relationship with GY $[\hat{y}(\mathrm{GY})=21.154+0.059 x(\mathrm{~K}), 0.53, p \leq 0.05]$.

In general, the foliar concentrations were found within the range indicated by Urano et al. (2006) as satisfactory, in contrast with the grain where the values were above the estimates from Moreira et al. (2017) for soybean crops under high productivity. Nutritional requirements of N, P, K, Ca, Mg, and S in the leaves had an average of the treatments following the order $\mathrm{N}>\mathrm{K}>\mathrm{Ca}>\mathrm{Mg}>\mathrm{P}>\mathrm{S}$, and in the grain it was $\mathrm{N}>\mathrm{K}>\mathrm{P}>\mathrm{Ca}>\mathrm{Mg}>\mathrm{S}$ (Table 4). Fageria et al. (2013) and Moreira, Moraes, and Fageria (2015) reported similar responses in the macronutrient concentration in leaves and grain of soybean.

\section{Physiological components}

Significant effects from $\mathrm{P}, \mathrm{K}$, and $\mathrm{S}$ rates were detected in the photosynthetic rate $(A)$, IWUE, and chlorophyll contents which varied from 13.1 to $17.4 \mu \mathrm{mol} \mathrm{CO}_{2} \mathrm{~m}^{-2} \mathrm{~m}^{-1}, 4.0$ to $5.3 \mathrm{mmol} \mathrm{H}_{2} \mathrm{O} \mathrm{m}^{-2}$ $\mathrm{s}^{-1}$, and 247.1 to $273.3 \mathrm{mg} \mathrm{m}^{-2}$, respectively (Table 5). The stomata conductance (Ci), intercellular concentration of $\mathrm{CO}_{2}$, and transpiration rate (Trmmol) despite being straightforwardly related to the photosynthesis were not affected by the treatments (Table 5). Based on Malavolta (2006) and Fageria (2009), these results occur because P acts, among other functions, in the storage and transfer of energy and the $\mathrm{K}$ in the opening and closing of the stomata, which make both nutrients been straightforward related with the respiration and photosynthesis. Even with the increases of the $A$ level because of $\mathrm{P}$ and $\mathrm{K}$ rates increases, the values stayed below the estimates from Lauer and Shibles (1987). Within K rates, as reported by Reddy and Zhao (2005), A concentration had quadratic and linear effects with chlorophyll levels (Table 5). Based on foliar $\mathrm{K}$ concentration, both variables had negative relationship $(\hat{y}=24.431-0.144 x, r=-0.58$ and $\hat{y}=26.304-0.016 x, r=-0.44, p \leq 0.05)$. These relationships contradict our initial expectative because $\mathrm{K}$ is straightforwardly related to stomata opening and closing which is suitable to $\mathrm{CO}_{2}$ entrance in the foliar mesophyllum and increases the internal concentration, and thus photosynthesis rate and chlorophyll content (Taiz and Zeiger 2006).

\section{Conclusion}

The formulated fertilizer application is the way of reducing the costs of crop yield. The $\mathrm{P}, \mathrm{K}$, and $\mathrm{S}$ interaction indicated that in current soil conditions, the content of $3.9 \mathrm{mg} \mathrm{kg}^{-1}$ of available $\mathrm{P}$ in the soil (Mehlich 1 extractant) was satisfactory to supply the nutritional requirements of soybean. The higher GY was found from the treatment $\mathrm{P}_{1} \mathrm{~K}_{2} \mathrm{~S}_{2}$ and lowest from $\mathrm{P}_{0} \mathrm{~K}_{0} \mathrm{~S}_{0}$, indicating that $\mathrm{K}$ and $\mathrm{S}$ were the nutrients that promoted the highest increased in the GY, in contrast to SDW; the P rates also had influence on the responses. Treatments without K application had lower GY, followed by $\mathrm{S}$ and $\mathrm{P}$. Based on the yield components and physiological and nutritional status, the responses indicated that the NGP is related to GY in contrast with SDW; the foliar and grain $\mathrm{P}, \mathrm{K}$, and $\mathrm{S}$ concentration had significant association with the respective treatments, but the $A$ levels, IWUE, and chlorophyll had influence from $\mathrm{P}$ and $\mathrm{K}$ rates.

\section{Acknowledgments}

We thank to the Santa Rita Laboratory by the soil analyses, the UNESP Ilha Solteira by the foliar and grain analyses, and the $\mathrm{CNPq}$ (Conselho Nacional de Pesquisa e Desenvolvimento) by the scholarship to the first author. 


\section{References}

Adams, F. 1984. Crop response to lime in the Southern United State. In Soil acidity and liming, ed. F. Adams, 211-65. Madison, WI: America Society of Agronomy.

Allen, S. E., G. L. Terman, and L. B. Clements. 1976. Greenhouse techniques for soil-plant-fertilizer research. Muscle Shoals, USA: National Fertilizer Development Center.

Baligar, V. C., N. K. Fageria, and Z. L. He. 2001. Nutrient use efficiency in plants. Communications Soil Science and Plant Analysis 32:921-50.

Borkert, C. M., C. Castro, F. A. Oliveira, D. Klepker, and A. Oliveira Júnior. 2005. Potash in soybean crop. In Symposium on potash in Brazilian agriculture [Simpósio sobre Potássio na Agricultura Brasileira], ed. T. Yamada, and T. L. Roberts, 671-722. Piracicaba, Brazil: Potafos.

Broch, D. L., P. S. Pavinato, J. C. Possentti, T. N. Martin, and E. M. Del Quiqui. 2011. Soybean grain yield in Cerrado region influenced by sulphur sources. Revista Ciência Agronômica 42:791-96.

Cassel, D. K., and D. R. Nielsen. 1986. Field capacity and available water capacity. In Methods of soil analysis: Physical and mineralogical methods, ed. A. Klute, 901-26. Madison, WI: America Society of Agronomy.

EMBRAPA (Empresa Brasileira de Pesquisa Agropecuária). 1997. Manual of soil analysis methods, 2nd ed. Rio de Janeiro, Brazil: National Research Center for Soils.

Fageria, N. K. 2009. The use of nutrients in crop plants. Boca Raton, USA: CRC Press.

Fageria, N. K., and V. C. Baligar. 2008. Ameliorating soil acidity of tropical Oxisols by liming for sustainable crop production. Advances in Agronomy 99:345-99.

Fageria, N. K., H. R. Gheyi, M. C. S. Carvalho, and A. Moreira. 2016. Root growth, nutrient uptake and use efficiency by roots of tropical legume cover crops as influenced by phosphorus fertilization. Journal of Plant Nutrition 39:78192.

Fageria, N. K., A. Moreira, C. Castro, and M. F. Moraes. 2013. Optimal acidity indices for soybean production in Brazilian Oxisols. Communications in Soil Science and Plant Analysis 44:2941-51.

Fageria, N. K., A. Moreira, L. A. C. Moraes, and M. F. Moraes. 2014. Influence of lime and gypsum on yield and yield components of soybean and changes in soil chemical properties. Communications in Soil Science and Plant Analysis 45:271-83.

Fageria, N. K., and J. P. Oliveira. 2014. Nitrogen, phosphorus and potassium interaction in upland rice. Journal of Plant Nutrition 37:1586-600.

Fageria, N. K., A. B. Santos, and M. F. Moraes. 2010. Yield, potassium uptake, and use efficiency in upland rice genotypes. Communications in Soil Science and Plant Analysis 41:2676-84.

Fehr, W. R., C. E. Caviness, D. T. Burmood, and J. S. Pennington. 1971. Stage of development description for soybeans (Glycine max (L.) Merrill). Crop Science 11:929-31.

Fox, R. L., H. M. Atesalp, D. H. Kampbell, and H. F. Rhoades. 1964. Factors influencing the availability of sulfur fertilizers to alfalfa and corn. Soil Science Society Proceedings 28:406-08.

Foy, C. D. 1984. Physiological effects of hydrogen, aluminum, and manganese toxicities in acid soil. In Soil acid and liming, ed. F. Adams, 57-97. Madison, USA: American Society of Agronomy.

Fritschi, F. B., and J. D. Ray. 2007. Soybean leaf nitrogen, chlorophyll content, and chlorophyll a/b ratio. Photosynthetica 45:92-98.

Hicks, C. R. 1973. Fundamental concepts in the design of experiments. New York, USA: Holt: Rinehart and Winston.

Janzen, H. H., and J. R. Bettany. 1987. The effect of temperature and water potential on sulfur oxidation in soils. Soil Science 144:81-89.

Lauer, M. J., and R. Shibles. 1987. Soybean leaf photosynthetic response to changing sink demand. Crop Science 27:1197-201.

Malavolta, E. 2006. Manual of mineral nutrition of plants[Manual de Nutrição Mineral de Plantas]. Piracicaba, Brazil: Editora Ceres.

Malavolta, E., G. C. Vitti, and A. A. Oliveira. 1997. Evaluation of nutritional status of plants; principles and application [Avaliação do Estado Nutricional de Plantas; princípios e aplicações]. Piracicaba, Brazil: Potafos.

Marschner, P. 2012. Mineral nutrition of higher plants. London, UK: Academic Press.

Moreira, A., N. K. Fageria, and A. Garcia Y Garcia. 2011. Effect of liming on the nutritional conditions and yield of alfalfa grown in tropical conditions. Journal of Plant Nutrition 34:1107-19.

Moreira, A., and L. A. C. Moraes. 2016. Sulfur use efficiency in soybean cultivar adapted to tropical and subtropical conditions. Communications in Soil Science and Plant Analysis 47:2208-17.

Moreira, A., L. A. C. Moraes, and N. K. Fageria. 2015. Variability on yield, nutritional status, soil fertility, and potassium-use efficiency by soybean cultivar in acidic soil. Communications in Soil Science and Plant Analysis 46:2490-508.

Moreira, A., L. A. C. Moraes, G. Schroth, F. J. Becker, and J. M. G. Mandarino. 2017. Soybean yield and nutritional status response to nitrogen sources and rates of foliar fertilization. Agronomy Journal 109:1-11. 
Moreira, A., G. J. Sfredo, L. A. C. Moraes, and N. K. Fageria. 2014. Agronomic efficiency of two types of lime and phosphate fertilizer sources in Brazilian Cerrado soils cultivated with soybean. Communications in Soil Science and Plant Analysis 45:2319-30.

Raij, B. V. 2011. Soil fertility and nutrient management [Fertilidade do Solo e Manejo de Nutrientes]. Piracicaba, Brazil: Potafos.

Reddy, K. R., and D. Zhao. 2005. Interactive effects of elevated $\mathrm{CO}_{2}$ and potassium deficiency on photosynthesis, growth, and biomass partitioning of cotton. Field Crops Research 94:201-13.

Rosolem, C. A. 2005. Potash interaction with other ions. In Symposium on potash in brazilian agriculture [Simpósio sobre Potássio na Agricultura Brasileira], ed. T. Yamada, and T. L. Roberts, 239-60. Piracicaba, Brazil: Potafos.

Sfredo, G. J., and A. Moreira. 2015. Efficiency of sulfur application on soybean in two types of Oxisols in Southern Brazil. Communications in Soil Science and Plant Analysis 46:1802-13.

Sfredo, G. J., E. Paludziyzyn Filho, and E. R. Gomes. 1994. Soybean response to potassium and phosphorus in a Paleudult soil at Balsas, MA. Pesquisa Agropecuária Brasileira 202:429-32.

Taiz, L., and E. Zeiger. 2006. Plant physiology, 4th ed. Sunderland: Sinauer Associates.

Tedesco, M. J., C. Gianello, C. A. Bissani, H. Bohnen, and S. J. Volkweiss. 1995. Analysis of soils plants and others materials [Análise de solo, plantas e outros materiais]. Porto Alegre, Brazil: : UFRGS.

TPS. (Tecnologias de Produção de Soja). 2013. Technology of soybean yield in central region of Brazil. Londrina, Brazil: Embrapa Soybean.

Urano, E. O. M., C. H. Kurihara, S. MAeda, A. C. T. Vitorino, M. C. Gonçalves, and M. E. Marchetti. 2006. Soybean nutritional status evaluation. Pesquisa Agropecuária Brasileira 41:1421-28.

Usherwood, N. R. 1982. Potash interaction with other ions [Interação do potássio com outros íons]. In Potash in Brazilian agriculture [Potássio na Agricultura Brasileira], ed. T. Yamada, K. Igue, O. Muzilli, and N. R. Usherwood, 227-47. Piracicaba: Brazil: Instituto da Potassa \& Fosfato.

Ward, R. C., E. J. Langin, R. A. Olson, and D. D. Stukenholtz. 1963. Factors responsible for poor response of corn and grain sorghum to phosphorus fertilization. Soil Science Society America Proceedings 27:326-30.

Wilson, J. B. 1993. Macronutrient (NPK) toxicity and interactions in the grass Fescuta avina. Journal of Plant Nutrition 16:1151-59.

Zhong, W., C. Schobert, and E. Komor. 1993. Transport of magnesium ions in the phloem of Ricinus communis L. seedlings. Planta 190:114-19. 